\title{
DISKUSSIE
}

\section{IETS ONTBREEK}

$\mathrm{Na}$ aanleiding van ' $n$ boek van ds. J. Overduin: Is geloven moeilijker dan vroeger? Kok, Kampen, sonder jaartal.

Soos van Overduin se ander boeke wat ek gelees het, boei hierdie een eweneens. Ook al verskil 'n mens plek-plek. Dit geld veral die derde hoofstuk waarin die skrywer ingaan op die vraagstuk van God en die lyde.

Hy sê dat daar baie misverstande oor die saak bestaan en valse probleemstellings gereeld op tafel kom met die gevolg dat valse antwoorde gegee word op vrae dienaangaande. Volgens 0 . is daar drie moontlikhede in verband met die saak:

1. Daar is geen verband tussen God en lyde nie, want God is dood. „Op deze manier behoeft men zich niet te vermoeien en niet te pijnigen met het slaan van een brug vanuit de lijdende mensheid naar God", p. 44.

2. God wil elke vorm van lyde. So het Hy van ewigheid af besluit. $\mathrm{Hy}$ is die Aanspreeklike ten aansien van die verskriklikhede in ons wêreld. „Geen wonder dat ontelbaar velen bij zulk een voorgeschotelde oplossing in opstand zijn gekomen en hun geloof in God verloren hebben. Hij is immers de diepste oorzaak van alle kwaad", p. 44.

3. Daar is 'n derde moontlikheid, soos die Skrif dit aan ons verkondig. Die groot probleem is dat baie mense die vraagstuk vanuit één hoek bekyk en nie ander faktore ter sake ag nie, bv. natuur, erflikheid, politieke en ekonomiese strukture ens. Al genoemde dinge speel 'n rol in lyde, maar nou maak mense die fout om die rolle te verwissel, m.a.w. die aandeel van die duiwel, die mens, die natuur e.s.m. word op rekening van God geskryf. As ' $n$ roekelose bestuurder 'n kind doodry, dan is dit tog daardie bestuurder wat die daad gedoen het. As ons gaan sê God was die oorsaak, dan het ons tog die mens met sy verantwoordelikhcid totaal buite spel geplaas. Overduin ag menslike vryheid, menslike verantwoordelikheid, menslike speelruimte van die uiterste belang om 'n Skrifgefundeerde antwoord op die onderhawige vraagstuk te gee, vgl. pp. 47, 48. By 'n ongeluk bv. tref ons die arts aan, die slagoffer, ooggetuies, die skuldige. God wil ook aanwesig wees met 'n positiewe doel, $\mathrm{nl}$. om te help, te troos, te bemoedig.

Maar wat dan van die Kategismus, Sondae 9 en 10? vra Overduin? Immers, by herhaling hoor ons die woordjie ,alles" in hierdie Sondagsafdelings. Al die kwaad wat Hy oor my beskik en alle dinge nie by toeval nie, maar uit sy vaderlike hand ons toekom. Hoe moet ons dit uitlê? „Het kwaad kwam uit de hand van de zondige mens, maar God wil er beslag op leggen, zodat Hij het ter hand neemt. En nu pas mogen wij-nadat God het kwaad ter hand genomen heeft om het te regeren - zeggen dat alles uit Zijn vaderhand kom. Hij wil het zó ter hand nemen, dat Hij machtig is om met een kromme stok, nog rechte slagen te doen." 
Die skrywer illustreer sy redenasie met enkele voorbeelde uit die Skrif. Wanneer Nebukadnesar Juda onder stof loop, dan is die dryfvere o.a. hoogmoed en geldingsdrif - iets waaroor God sy oordeel sal laat kom, seker. Maar dit kom nie uit Gods vaderhand nie, dog Hy neem Nebukadnesar se inval (sonde) ter hand om sy volk te louter en tot inkeer te bring.

Tweede voorbeeld: Paulus sê nie dat dit die Here is wat hom slaan nie, maar 'n engel van die Satan. Maar hiermee het die Here 'n doel: om Paulus klein te hou, ,,zodat het met een zinvolle bedoeling nu uit Zijn Vaderhand komt." Soortgelyke gedagtes kom ook voor in die boek van Prof. J. Heyns: Dogmatiek, 1978, p. 153. God begrens die sonde (dit het nie vryspel nie), God benut die sonde (gebruik dit ten goede vir sy kinders). Maar dan gaan Heyns voort en sê: God bestraf die sonde. En dit is met name hierdie gesigspunt wat ek mis by Overduin. Om weer terug te keer na sy twee voorbeelde van so ewe: natuurlik handel Nebukadnesar uit hoogmoed en geldingsdrif as hy opruk teen Juda, en hy is wel deeglik gestraf deur God. Maar die Bybel sê nadruklik dat God hom gebring, gestuur het om die volk te straf. Hier is toornwerking aan die gang; die koning kom nie net uit eie aandrif nie, en dit is vir my nog iets anders as net: ter hand neem.

'n Engel van die Satan slaan Paulus, nie die Here nie. Maar die apostel sê self dat 'n doring in die vlees aan hom gegee is, die onderwerp van hierdie gee is duidelik die Here. Dat die engel van die Satan sy eie redes gehad het wanneer hy slaan is ongetwyfeld korrek, maar hy is losgelaat teen Paulus deur Iemand anders.

In die Hebreërbrief beluister 'n mens opmerklike klanke: daar is sprake van tugtiging waarmee die Here sy kinders besoek; tug as opvoeding, Hebr. $12: 7$ e.v.v. O.i. kan daar geen twyfel oor bestaan nie dat tug hier nie vir 'n oomblik van sy aanvang af, geīsoleerd van God gesien word nie, so asof Hy eers dan pas ter sprake kom wanneer iets of iemand sy kind leed aangedoen het. Nee, Hy neem die inisiatief van meetaf aan, sonder om daarmee vir 'n oomblik te ontken dat ander instansies of magte ook in die prentjie is.

Die vraag bly by my: is Overduin se sieninge nie miskien die resultaat van 'n versmalde of gereduseerde Godsbeeld nie? Ek bedoel: word die toorn van God nie afgeswak of selfs geëlimineer nie?

Toorn en lyding.

Tugtiging en lyding.

Intussen sal ons vir een ding tog moet oppas: naamlik om só oor lyde te praat van die "faktore" soos Overduin hulle noem, geminimaliseer word, selfs verswyg word. Die roekelose motorbestuurder het sy verantwoordelikheid en wie dit wil wegredeneer laat nie reg geskied aan die Bybel nie. As Overduin ons hierteen wou waarsku - en kennelik wil hy - dan kan ons hom dankbaar wees.

Maar nie sonder die goddelike inisiatief nie!

(Ds.) H. M. GROBLER. 